Proceedings

\title{
Silent Books. Wonder, Silence and Other Metamorphosis in Wordless Picture Books ${ }^{\dagger}$
}

\author{
Marcella Terrusi \\ Grant Researcher Children's Literature and Education, Department for Quality Life Studies-University of \\ Bologna, 47921 Rimini, Italy; marcellaterrusi@hotmail.com; Tel.: +39-339-769-6377 \\ + Presented at the International and Interdisciplinary Conference IMMAGINI? Image and Imagination \\ between Representation, Communication, Education and Psychology, Brixen, Italy, 27-28 November 2017. \\ Published: 1 March 2018
}

\begin{abstract}
In the field of children's literature, wordless picture books, or silent books, are visual narrations offering readers the chance to experiment new ways of reading images and using words. They represent precious contexts for negotiation and co-construction of meaning; not requiring translation, they travel beyond editorial borders, creating a collective discourse telling of the world through pictures: privileged poetic themes are wonder, the discovery of pictures of art and other languages, metamorphosis, the amazement triggered by the critical capacity of projects that draw attention, in silence, to both details and "big picture" as a whole.
\end{abstract}

Keywords: children's literature; wonder; reading promotion; wordless picture books; silent books; illustration; imagination; silence; visual narrative

\section{Introduction}

Wonder, marvel, astonishment and surprise are emotional and aesthetical qualities, but also the keywords when we talk about visual art, childhood and children's picture books. Wonder and marvel, indeed etymologically we find ourselves in an area connected with the exercise of seeing and looking, are emotions we begin feeling since our birth. Someone said that early childhood can be seen as a time in which every human being is speechless with surprise. Marvel is what reaches us through the eyes. If it's true that there are different ways of seeing, childhood definitely is the crucial time in which we lay the foundations of our grammar and attitude to discover the visual world. John Berger in his Ways of Seeing wrote that "seeing comes before words" [1].

Talking about children's picture books means referring to those literary and metaphorical gardens, windows, mirrors and mandalas where we are invited to launch, develop and experience our visual way of being in the world in an active way. Visual narratives in picture books can be seen as small-scale worlds that welcome and take us through the complex dynamic of reading and interpreting cultural, natural and inner images that we see.

This paper focuses on children's picture books with a special characteristic, i.e. those wordless, pure, visual storytelling in the shape of books that tell stories in pictures. Even if they belong to children's publishing, we cannot avoid considering them as real crossover, also supported by the words of a great artist in this genre, the award-winning author known across the globe for his masterpiece The Arrival [2]. His name is Shaun Tan and here is what he wrote:

Who are my books for? They are for as many different people as possible. I just trust that we all have something extremely valuable in common: an unpredictable imagination... As a creator, you provide a little architecture, build some imaginary walls, add a few furnishings, then wait for an anonymous visitor to arrive: should they accept the invitation, any real meaning can only come from their own hearts and minds... The reader is not so much the 
recipient of ideas; they are a conversationalist, enjoying a language that transcends the ordinary boundaries of daily chit-chat. All we need to do as creators and readers sitting together in the imaginary guest room is look at things and wonder about them openly. ([3]. p. XIII, XIV).

Tan reflects about the wordless book as a real "open work", as Umberto Eco would say [4] that revoke the imagination and the voice of the reader. Shaun Tan wrote these words as an introduction to a book published by Bloomsbury in 2014, entitled Visual Journey Through Wordless Narrative; An international inquiry with immigrant children and The Arrival [5]. He refers to the active role of the reader and in fact in the experience of collective reading of wordless books retold during this research it has been found that these are truly silent scores for the reader's voice. Pedagogists from four countries and universities - Great Britain, Spain, United States and Italy-carried out experiences of collective reading of the wordless book The Arrival involving immigrant pupils aged 10 and 11. Team leader Evelyn Arizpe, one of the scholars who has dedicated most theoretical and empirical research to this topic, worked with Teresa Colomer and Carmen Martínez-Roldán according to a shared protocol, in order to gather and compare their observations of readings with children. For what concerns the Italian experience [6-7], borrowing one of Tan's expressions, we sat, the author of this contribution and Giorgia Grilli, in a guest room with some young readers and together crossed the visual narration of The Arrival, a story of migration told only through pictures; we observed how this kind of narration stimulates the production of language, since collective reading of picture books is a continuous negotiation of meanings and different perspectives, a rigorous questioning of all the details and structure of the visual text, an experience of disorientation and construction of meaning, and above all the sharing of wonder and thus the construction of deep relationships between readers and between readers and authors. Finally we could prove that wordless books are a genre of its own, with a privileged access to some poetic themes, its grammar and its specific aesthetic and pedagogical possibilities. The aim of this paper is to illustrate some of the reflections and finding about wordless picture book that were developed from an interdisciplinary, critical, theoretical, historical and point of view. The perspective is more the anything poetical, meaning with that a special interest into the world vision's of that authors, who devote and address their visual narratives to the crossover audience of wordless picture books readers, narrative views and visions that we find fundamental contributions for a visual and aesthetical contemporary education.

\section{Changes in Pages: Historical and Critical Notes}

The systematic study of wordless books is a relatively recent field [8] and the theoretical references of the subject investigated, dealing with children's literature, necessarily belong to a range of disciplines-education, narratology, iconography, philosophy, literary criticism and art critic. According to the method used by the Bologna school, which refers to the teachings of Antonio Faeti, pictures in children's books must always be considered in relation to the whole visual and artistic culture, with their apparatus of metaphors, references, filiations and respective grammars. A student of the philosopher Luciano Anceschi, who devoted many reflection about the poetical views of authors in literature as their ways to depict the worlds, Faeti since his pioneering essay Guardare le figure [9] has always addressed to the production of children's images and illustrations the attention of those who think that looking at pictures it is in the experience where the ability to see is built; in illustration picture's makers offer hospitality for children meaning in this way that they are part of an active cultural community which aims to exercise critical ways of seeing and that children belong and are part of the collective imagination from very early childhood on. In this sense, asking which children's poetics and poetics of the world are chosen by the authors of children's visual and literary works means asking about the ways in wich construction of our view of the world grow up from childhood on.

In children's publishing, there is an implicit-and at times explicit-editorial position, which refers to one or more ideal recipients who are willing to "sit together" and look and read together. This is the typical dual audience of the picture book, as stated by Sandra Beckett in her essay Crossover 
Picturebooks in which, in 2012, the researcher dedicated also a whole chapter to wordless books, reconstructing some historically relevant moments and reviewing some classics [10].

In Italy, thanks to pioneers such as Bruno Munari and Iela and Enzo Mari, wordless books for children were designed first and foremost by distinguished visual designers interested in children's visual perception and the experimentation of book shapes. Among the pioneering examples of excellence in this book genre, we could mention in fact the illegible books by Bruno Munari [11] (Figure 1) and picture books which narrate natural cycles with few colours and rigorous forms such as La mela e la farfalla (Figure 2) by Iela and Enzo Mari [12] still reprinted today.

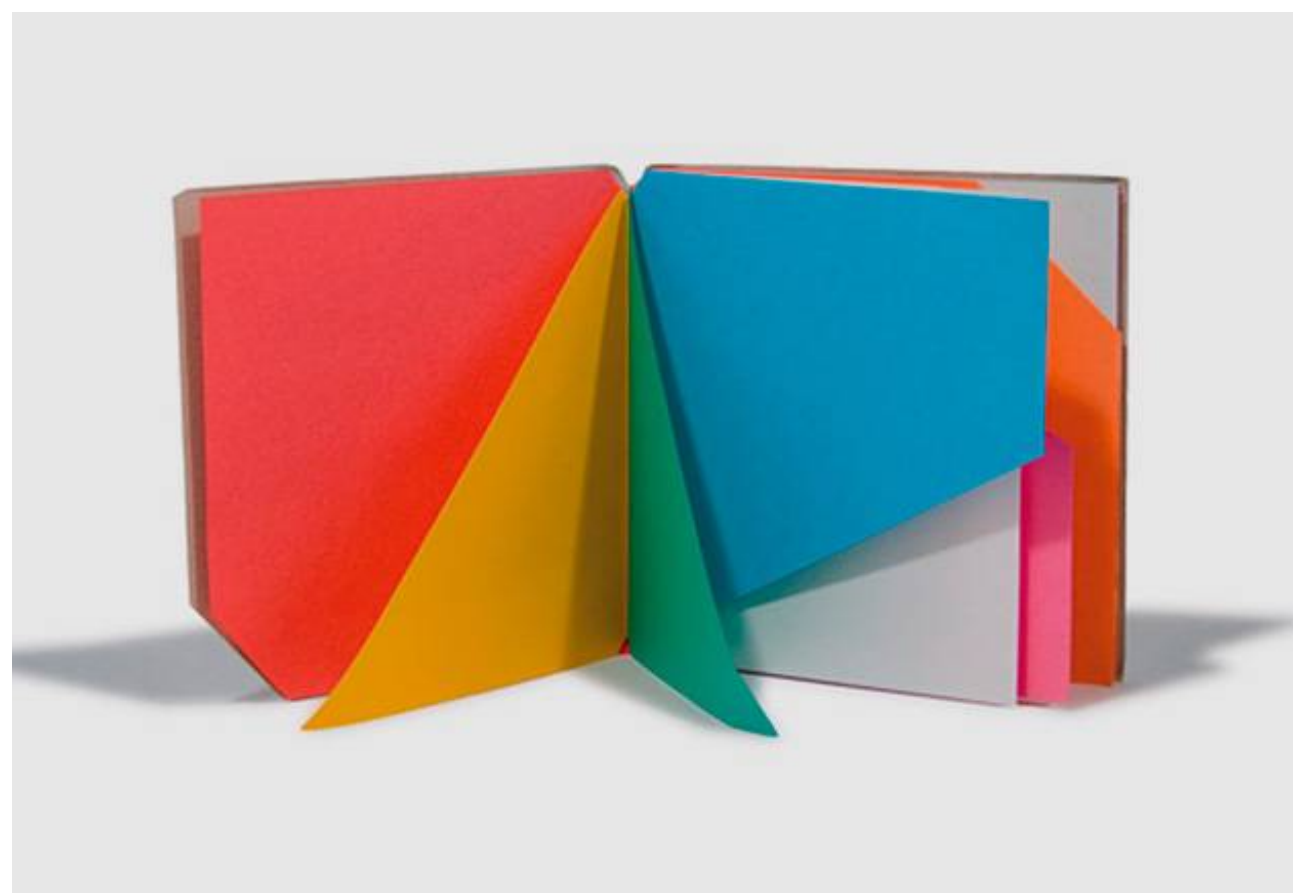

Figure 1. Munari B. (2009) Libro illeggibile "MnI", Corraini, Mantua.

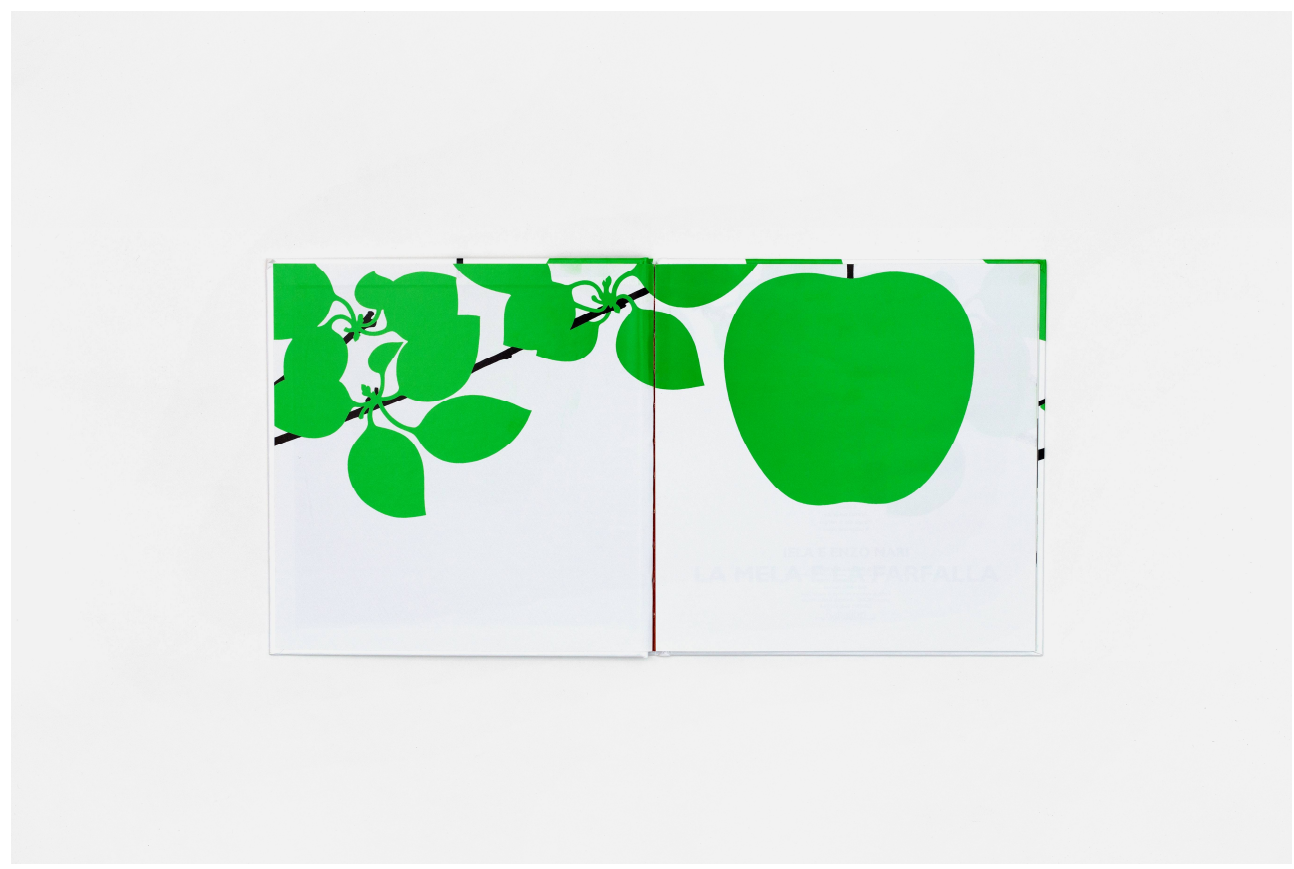

Figure 2. Mari I., Mari E. (2004), La mela e la farfalla, Babalibri, Milan.

The international historical perspective, i.e. that of Sandra Beckett or the Korean scholar Jiwone Lee [13], refers to these Italian experiences as concerning the roots of the modern art of wordless books. 
Broadening our view, we may suggest many possible genealogies for placing the visual narrations of books on a timeline. In this sense, the contemporary wordless children's book is simply one of the lively and continually changing heirs of the many "silent" narrations by images which have always characterised man's expression through figures, starting from the cave paintings in Lascaux to Trajan's Column and the pictorial cycles of Giotto and Paolo Uccello (Ducal Palace, Urbino), to the Biblia Pauperum ([8], p. 79) which talked to both illiterate and literate readers through contaminations with other languages as pantomime, the history of chronophotography, photography, cinematography, silent movies and even music, crossing the evolution of the book from codex to volumen and finally to printed books, and the evolution of the silent novel of the Thirties and cartoons like Lynd Ward's Novel in woodcuts. In the constant dialogue with visual design, children illustrations have always belonged to a coherent, cohesive universe, since their own grammars and the possibility of telling stories made of signs and shapes are as understandable and disorienting as the world itself.

The genealogies of the silent book therefore continuously refer to the book form and the child recipient and place different dictions and visions related to poetical themes and concepts such as silence, complicity, metamorphosis, wonder, silence and movement.

Among these, works which are very different in shape, recipients and contents have a special place: above all the ancestor book can be considered 1677's Mutus Liber ([8] p. 84), a silent alchemic manual on the Great Game whose pictures contains the instructions for the steps needed for transformation, legible and understandable only by the initiated. Addressing only the community with the interpretative skills required to read the pictures and organise them in such a way as to identify the precious indications for performing the steps in the Great Game. Worldess books are always addressing to a community that share common visual alphabets and collaborate to build this international and collective sharing of images and imagination.

In this regard, here is a terminological note: the expression silent book has been used only in the last decade and in Italy for the first time; then it spread to the international community and today used alongside the more pragmatic one wordless book. This has been possible also thanks to a more embellished and rhetoric linguistic vocation of Italians during the Silent Book Project for Lampedusa ([8] p. 43) promoted by the Italian branch of IBBY (International Board on Books for Young People), the major international non-profit organisation which promotes reading, and other international occasions. The allusion to silence can indeed be found in very many critical works dedicated to this type of picture book. The perceptive possibilities of seeing demand a type of concentration strictly linked to the exercise of the art of silence and observation, as in monasteries' traditions and meditation. Silence is not only a pedagogical possibility offered by this kind of narration, which breaks the chain of too many words of scholastic habits and reviews the educational hierarchies by facing with a text which does not necessarily need to be said by a literate reader in words in a loud voice but rather seen and read with the eyes and retold in new words for every reader. In pedagogical terms, it turns the traditional roles of reading upside down: the adult is no longer the first reader, the initiated side that knows the written sign and acts as a go-between, at times with a rather hurried approach, dulled by normative obsession or cognitive control, and loses the plot, while children are the dynamic readers of pictures, as John Amos Comenius underlined in the mid-17th century [13]. Silence is also one of the favourite poetic themes of silent narrations in itself, underlining an aesthetic intention and a clear aesthetic education. Silence in wordless books also means listening to other languages, those of signs, colors, visual sequences and shapes also, in a time that slows down and in that space of solitude where multiple narrations are possible.

In contemporary wordless books therefore meetings of new levels of narrative take place beyond words, through natural and fantastic metamorphosis and dreamlike spaces where imaginative and interior meanings are built and so invite to be discussed and considered.

Wordless books often tell stories about the very capacity of pictures to offer narrations crossing space and time, rich in that we call "visual culture".

Flotsam (Figure 3) by american three times Caldecott award winning David Wiesner [14], one of the masterpieces of this genre, is an authentic programmatic and metatextual manifesto. 


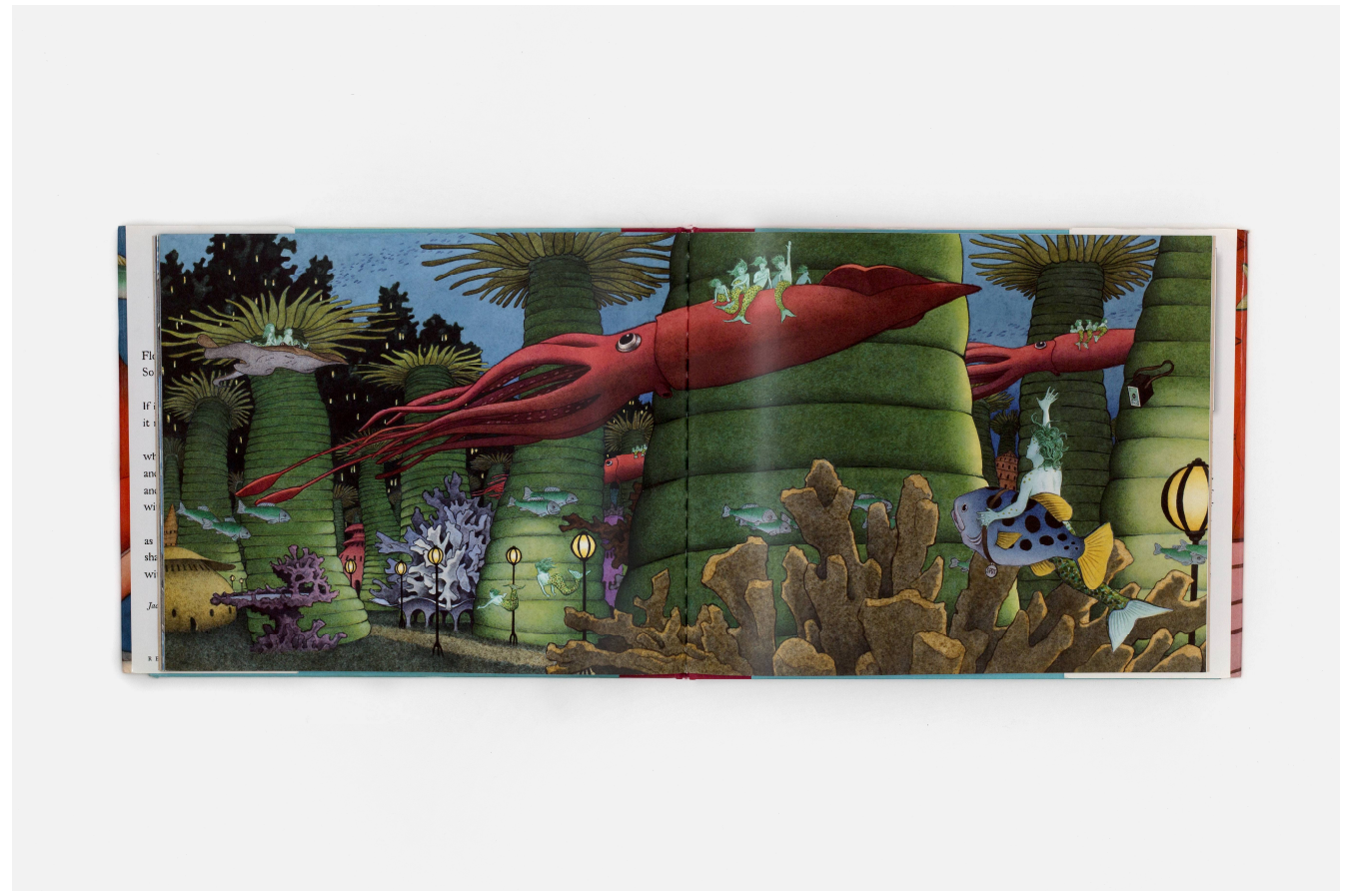

Figure 3. Wiesner D. (2006), Flotsam, Clarion Books, New York.

The underwater camera found by the lead character, a boy, is a device which declares not only the extraordinary power of cultural images and their circulation in space and time, but also confirms children's belonging to the visual universe of the collective imagination, that reservoir of interior and archetypical, cultural, natural, artistic and dreamlike visions in which our lives are immersed and from which our dreams, hopes and future narrations take shape. It is interesting to note how this is inline with the 1989 UN Convention on the Rights of the Child in articles 13 and 31 (The Convention on the Rights of the Child, approved by the UN on 20 November 1989, can be downloaded from the website of the Italian Ombudsman for Children and Adolescence: www.garanteinfanzia.org) an aesthetic right to "seek, receive and impart information and ideas of all kinds, regardless of frontiers, either orally, in writing or in print, in the form of art, or through any other media of the child's choice" and to have access to the greatest variety of high-quality artistic and cultural production.

Alongside the exercise of poetics and the aesthetic encounter are wonder and marvel: the sea in Flotsam is full of giant squids, lost objects and mermaids; an infinite sea like that of stories, literature and art, alternately suggesting familiarity and disorientation, moving towards knowledge and change; a sea of images evoking and containing worlds; a silent sea that animates, reawakens and narrates through pure vision without words. Also wonder leaves us wordless, as we read in the following passage by Silvano Petrosino ([15] p. 107):

Wonder does not wait for the spoken word, the explicit formulation (sound, graphics, or other forms) of the words, to be a word... The silence which always accompanies wonder... is not at all the expression of mutism, but rather the place of clamour, the condition of a continuous being questioned and answering, of being called on to answer... The time of wonder is not the momentary silence of glitter, the idolatrous suspension before what terrifies me, but it is a time of words in which this glitter animates-me-and-I-animate-it as a question.

Disorientation, wonder and marvel are aesthetical and existential conditions frequented by the silence of wordless books right from the very beginning. They are linked to the quality of humorism in one of the first books of this type, the work of the extraordinary Swiss-born French illustrator, Théophile Alexandre Steinlen who, in a short libretto of only pictures entitled The sad story of Bazouge [16] (Figure 4): places on the page a crow drinking from the glasses left on a sumptuously laid table after a meal. Page after page, the crow drinks and changes expressions: it is only his increasingly 
hallucinated stare and an uncertain posture in Steinlen's drawings that tell us what is changing in its mood. The crow drinks more and more, at the end of the libretto it is totally drunk and falls to the ground. The trick lies in turning the pages and following the author's visual capacity of observation, imagination and illustration, picturing the eye of the crow slowing down, moving away, moving back in, focusing - just like in the cinematic strategies - on what he is intent on, inviting the reader to look at the same thing. The silence of this sequence creates a very strong complicity between the author and the reader, and an humoristic irresistible effect, because the author of a wordless book looks confidently towards the reader's ability to read images, he does not take them by hand but shows only what he wants them to look at and to fill with meanings and emotions.

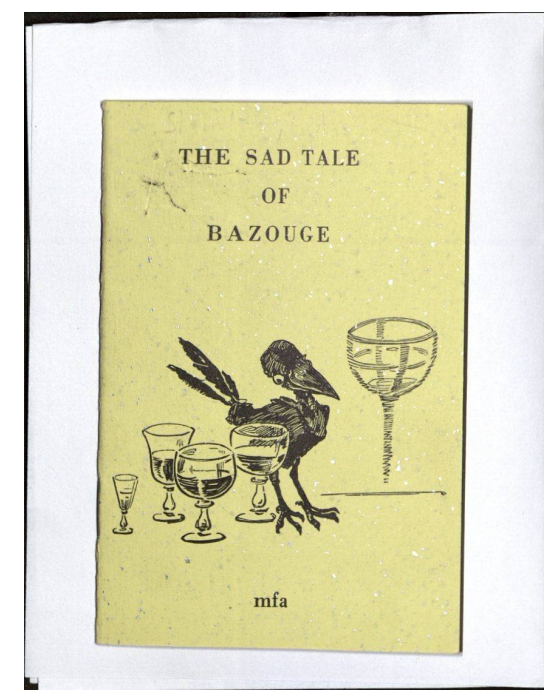

Figure 4. Steinlen T.A. (1961), The Sad Tale of Bazouge, Museum of Fine Arts, Boston.

Another mandatory historical reference, yet so eccentric and unclassifiable as to be a book not designed explicitly for children and printed by Italian publisher, designer and art collector, Franco Maria Ricci: Codex Seraphinianus [17] (Figure 5) first published in 1981, is a visionary and mysterious work created by the Italian designer Luigi Serafini, characterised by astonishing metamorphic figures in an imaginary world and an asemic text impossible to decipher.

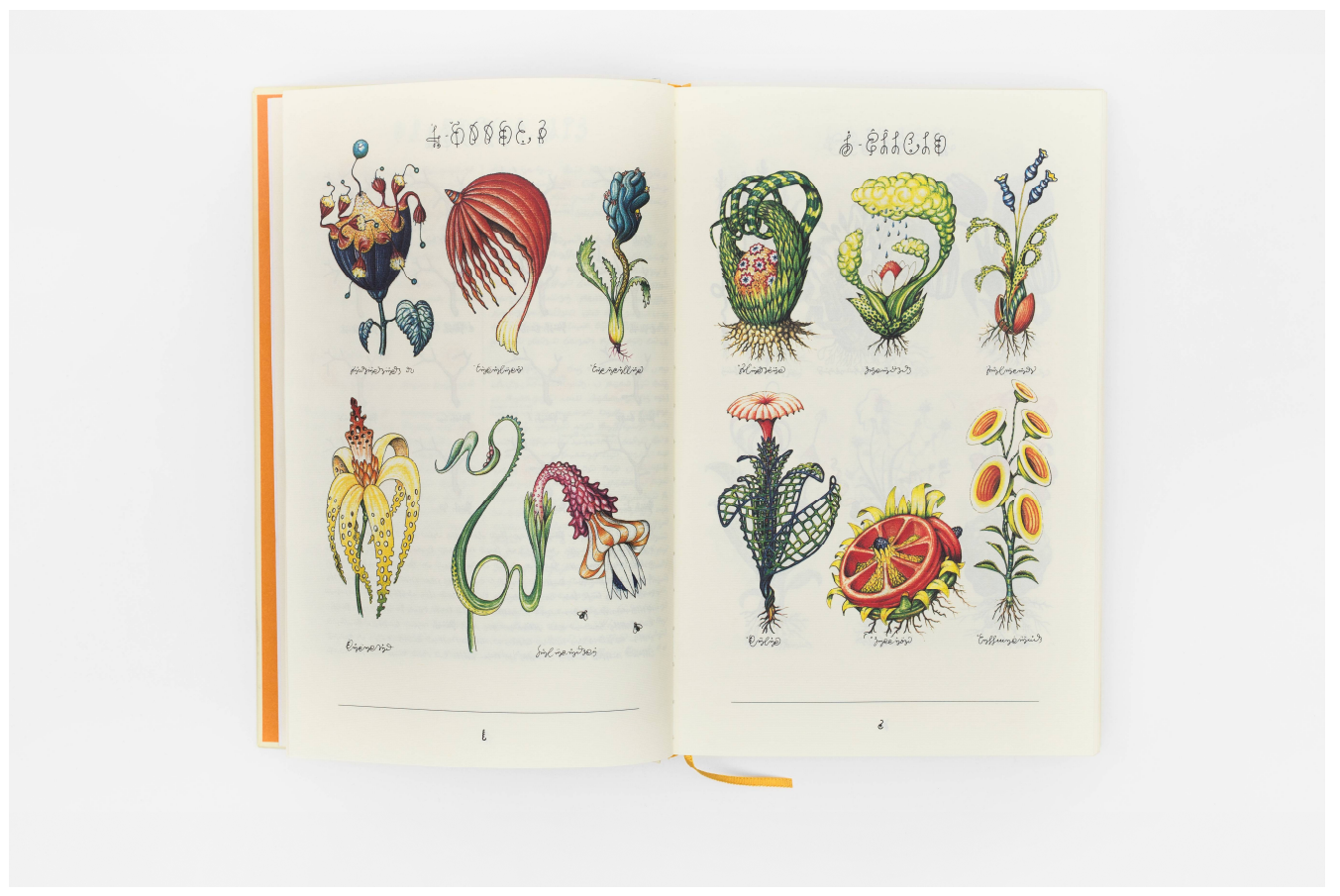

Figure 5. Serafini L. (1981), Codex Seraphinianus, Franco Maria Ricci Editore, Milano. 
Like forgotten ancestors, who continuously return to show themselves in the physiognomies and memories of their heirs, also artists as Edward Muybridge [18] and other precursors of the cinema, using chronophotography pursuing the aim of creating the moving world in pictures, impressed their recognizable signs and poetics in the grammars of the wordless book. The visual complex research into how to render time and movement, shared by different visual languages and form of art, combined with the poetics of the missing and empty spaces as a form of voluntary reticence being retold by visual sequences are elements that find the ideal space for expression in wordless picture books.

Thus the silent books on the contemporary international bookshelf tell of a girl playing with a wave (L'onda, by S. Lee [19]), the transformations of the world in a dream (Free Fall, by D. Wiesner [20]), journeys chasing signs and colours (Journey, by A. Becker [21]), migration challenging habitual signs and geographies The Arrival, by S. Tan [2]). They tell of unknown alphabets, knowledge of the metamorphosis of nature, the possibility to suspend verbal language to recover perception through other senses, the need to communicate beyond the boundaries of the word, diversity, the belonging of the mandala and the page symbolically to the cosmic universe, the belonging of those who are different, who have just arrived, whether migrant or child, to the collective imagination, and the right of this belonging and the occupancy of the world of signs and shapes.

They tell of the world in continuous movement and metamorphosis, in Iela Mari's books and in the Pat Hutchins's picture book Changes, Changes (Figure 6) [22], published at the same time as David Bowie's song of the same name, and in the dreamlike, surreal transformations we find in all David Wiesner's worldess picture books.

A more specifically narratological and pedagogical review of the silent book's poetics, in other words a review of the visions of the world that authors give in their narrations by images, reveals surprising repetitions. Metamorphosis, a great and universal literary theme, is often at the centre of a narration which thrives on sequences of pictures and relationships between forms and which regards childhood, that season of change par excellence, even though man is always evolving and is never really adultus [23] (etymologically, completed).

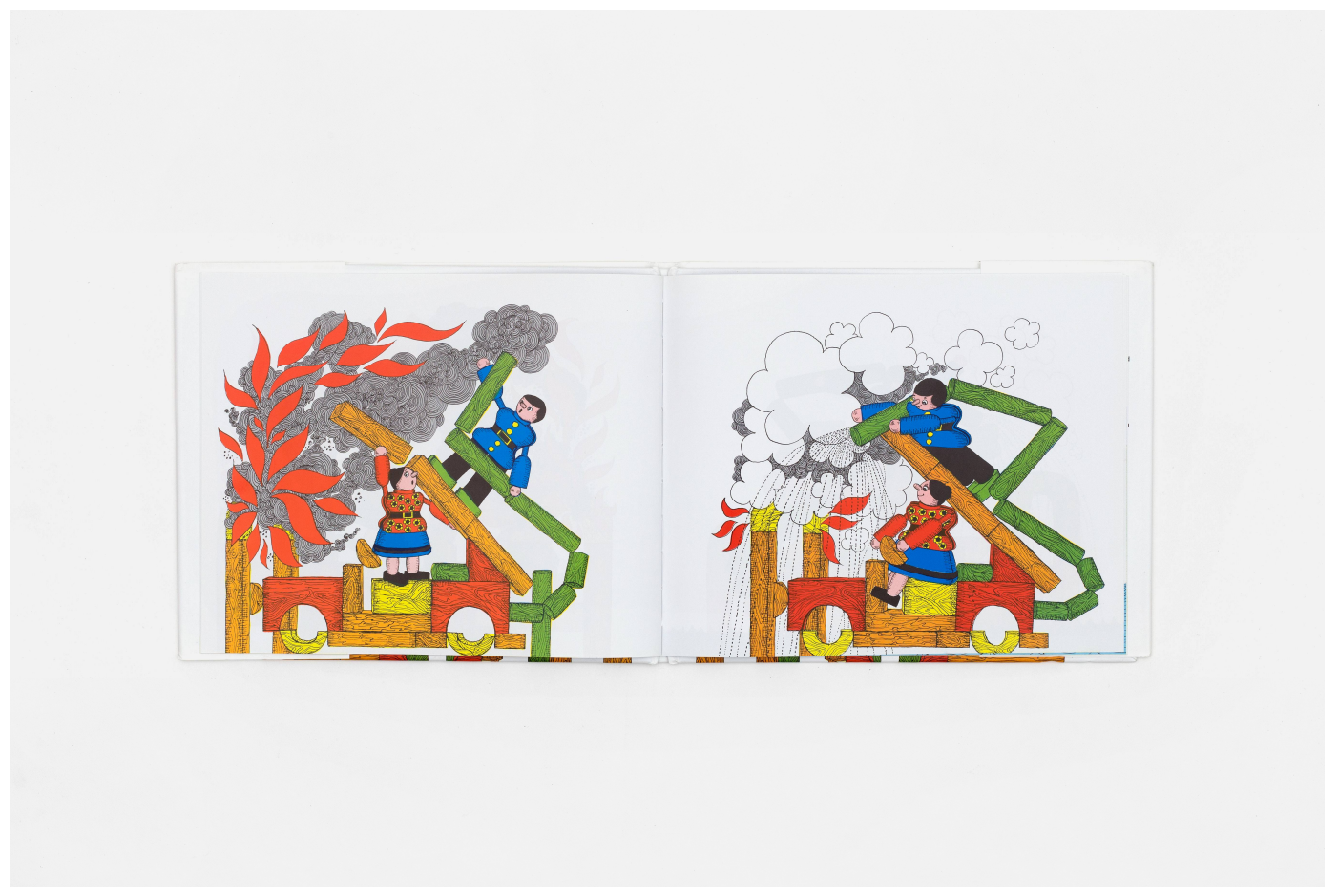

Figure 6. Hutchins P. (1971), Changes, Changes, Simon \& Schuster, New York.

Lacking, as a clues structured text or a poetical reticence or the space between moments and transformations phases, as the interest in what is invisibile, as indeed in all written literature, as demonstrated in Nicola Gardini's critical essay Lacuna [24] is also illustrated literature in pictures and 
visual narrative. The reader ventures through the pages and has to fill the signs with meaning, just as he fills the spaces between the words. Educators clearly fear this having to trust the author and his visual language, it is an exercise of faith which is not unrewarded, in the case of masterpieces of this genre. The thread of sense, or nonsense, leads the reader to turn back the pages to check theories, to jump in surprise at sudden revealing of meanings, or even laugh, or change his mind, when the page confirms or even upturns a previously interpreted theory. Thus the silent book teaches that literature is a place of shortcomings, a place of completions and suspensions, meetings with the imaginations of others, a possibility for the knowledge of man and his constitutional incompleteness. Thus the silent book invites adults, educators and readers to exercise lateral thinking and abandon normative certainty, reassessing the value of open questions and "big" thoughts [25] to the detriment of the need to continuously evaluate and measure the utilitarian acquisition of skills.

There are many surprises in the educational field when we experience reading wordless books: at the end of the Italian research Visual Journey (already quoted above) in the international project focusing on the reading Tan's The Arrival [2] (Figure 7) with immigrant children, more than one of the children involved, in a semi-structured interview, said that he had "learned Italian", even though this was not one of the objectives we set as researchers. During other interviews with the teachers, it was noticed that this was only one of the clearest facts reported after the experience, which lasted for a few weeks, of the collective reading as the other issues were decisive, including a greater motivation of children towards discovery not only of other books but also of dialogue with the class group, and peers, as well as a much greater self-esteem and trust in self-expression.

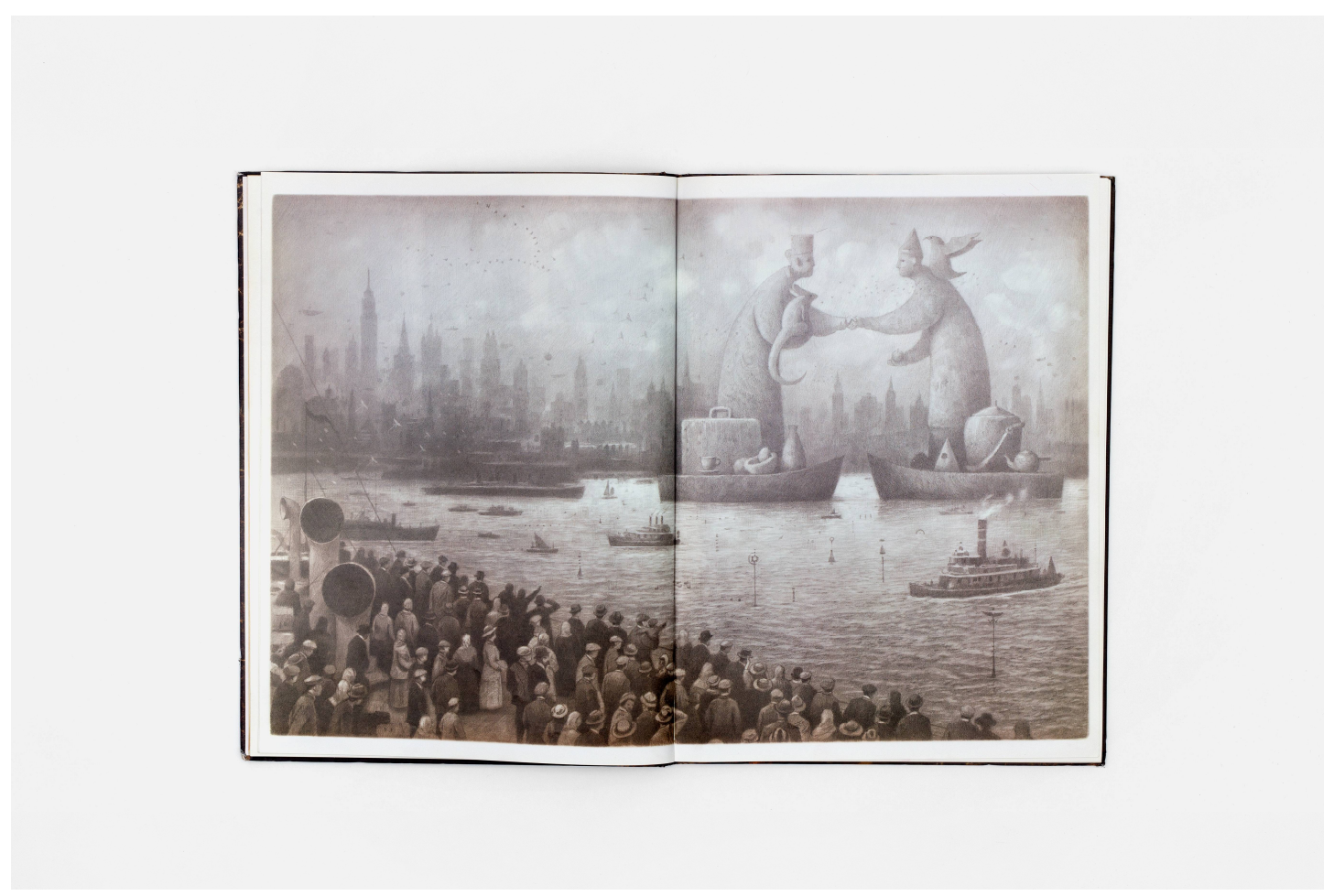

Figure 7. Tan S. (2016), L'approdo, Tunuè, Latina.

The story of a man who migrates to an unknown country, told only through pictures, in a programmatically disorienting symbolic and iconographic complexity had, together with the collective reading method, dilated the space of the book through open questions and mutual listening. In that silence, in the complicity of reading, visions, exchanges, stories and readings were produced and built a community of readers, through the exercise of the negotiation of meaning and co-construction, active citizenship was also exercised. The relationship among the readers and the urgency of sharing their own aesthetic experience were the drive for linguistic expression that was stronger than any form of teaching. The poetics of disorientation, of the metamorphosis and of the lacking are close to the sensitivity of children who continuously wonder about signs, clues or 
changing forms. Children, like artists, travellers and migrants, continuously experience disorientation, metamorphosis and suspension. They look at the very small, the detail, the minuscule, the insect, even the invisible with the same urgency as the very large, the immeasurable extent of the stars or time.

In the same way, silent books are part of this broad spectrum of poetic measures, sharing with Western and Eastern philosophy the interest for the very small and the very great. According with this perspective the picture book is itself a mandala, i.e., a coherent community of signs and shapes, continuously referring to the world beyond its frame. The theme includes not only art and spirituality but also science, as can be read in the magnificent book by US biologist David George Haskell, who observed and described the same portion of old-growth forest telling of the thousands of ecological relations taking place in the environment [26]. Image is mediator and mirror, window and summary of the world. The very small is also childhood itself, the everyday moment, the hidden detail to be found in every page. The very great is the circularity of natural metamorphosis, the continuum of every story that can be repeated infinitely, like the very story of the circulation of pictures and stories. The silent book confirms children's right to be informed and involved in this broadness of thought, vision and ecology of the mind [27], which is cultural, spiritual and aesthetic. Finally, the silent book invites us to see.

Wordless books or silent books are books which are usually composed of sequences that do not have the fast rhythm of the cartoon, but which offer a rarefied visual story, where the scene changes with every turn of the page, bringing metamorphosis and movements which are understandable even in early childhood and which constitute the very first possible discovery of the book-device. They are visual devices and artefacts that are far from simple, they attract and absorb visual designers who experiment the visual perception of children, the synthesis of shapes, the challenge of the synthetic narration of universal topics.

Therefore wordless books require the learning of alphabets to be understood, they require the knowledge of visual grammars, the habit of exercising the eye and the meeting with art, and do not possess - we refer to narrative silent books - millions of possible interpretations but rather precise paths of meaning set forth by the author, often on several levels, which the reader must follow, using-often openly declared-clues, in the several readings required of this type of book, a synthetic and yet complex form of poetics, just like poetry.

The metatextual discourse between image and imagination is also expressed in the large quantity of references and citations picture book authors disseminate in their works: internal references and references to traditional paintings, cinema, the history of photography.

The silent book is thus in a borderland, it makes the geography of the visible understandable and accessible to the very young providing a discourse that is readable in itself, beyond the very boundaries of languages, history, signs and forms. The border, the solitude, the silence and the experience of the limit and the crossing of it in the identity making process, as the meaning of empty space, the white color and lacking are other recurrent poetic themes represented in contemporary wordless books. The corean internationally acclaimed wordless picture book's author Suzy Lee devoted an essay to her art and called the illustrated volume The Border Trilogy (Figure 8) [28] where she proposes critic commenting about her wordless books Trilogy that includes L'onda (Figure 9 [19]), Ombra [29] and Mirror [30].

Lee writes about the white space of the page being an expressive choice and the limite between the two spreads a narrative element, capable of representing in images the relationship with the unknown, the unseen, the impredictable, so the possibility of experiencing wonder and surprise of discovery. 


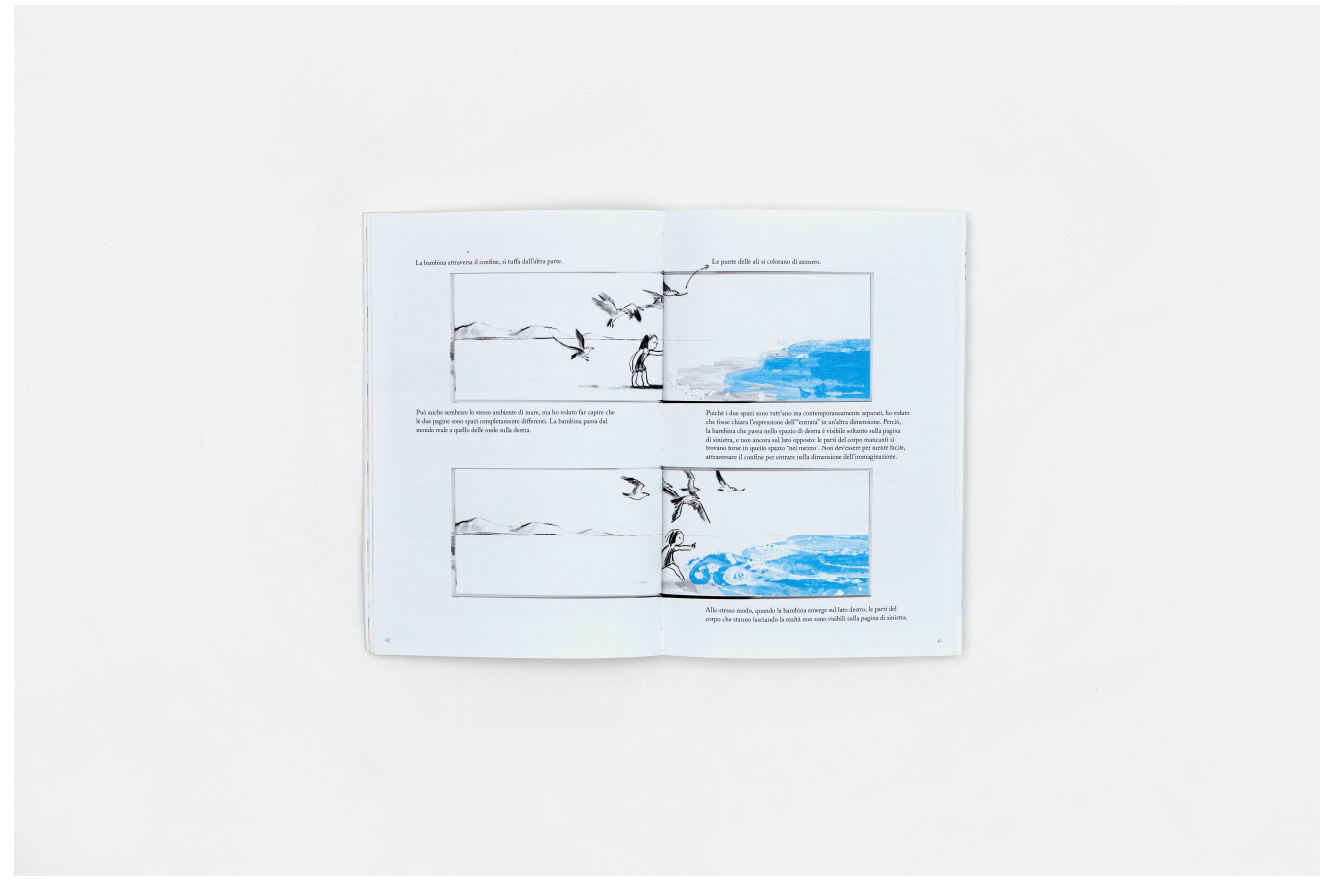

Figure 8. Lee S. (2012), La trilogia del limite, Corraini, Mantua.

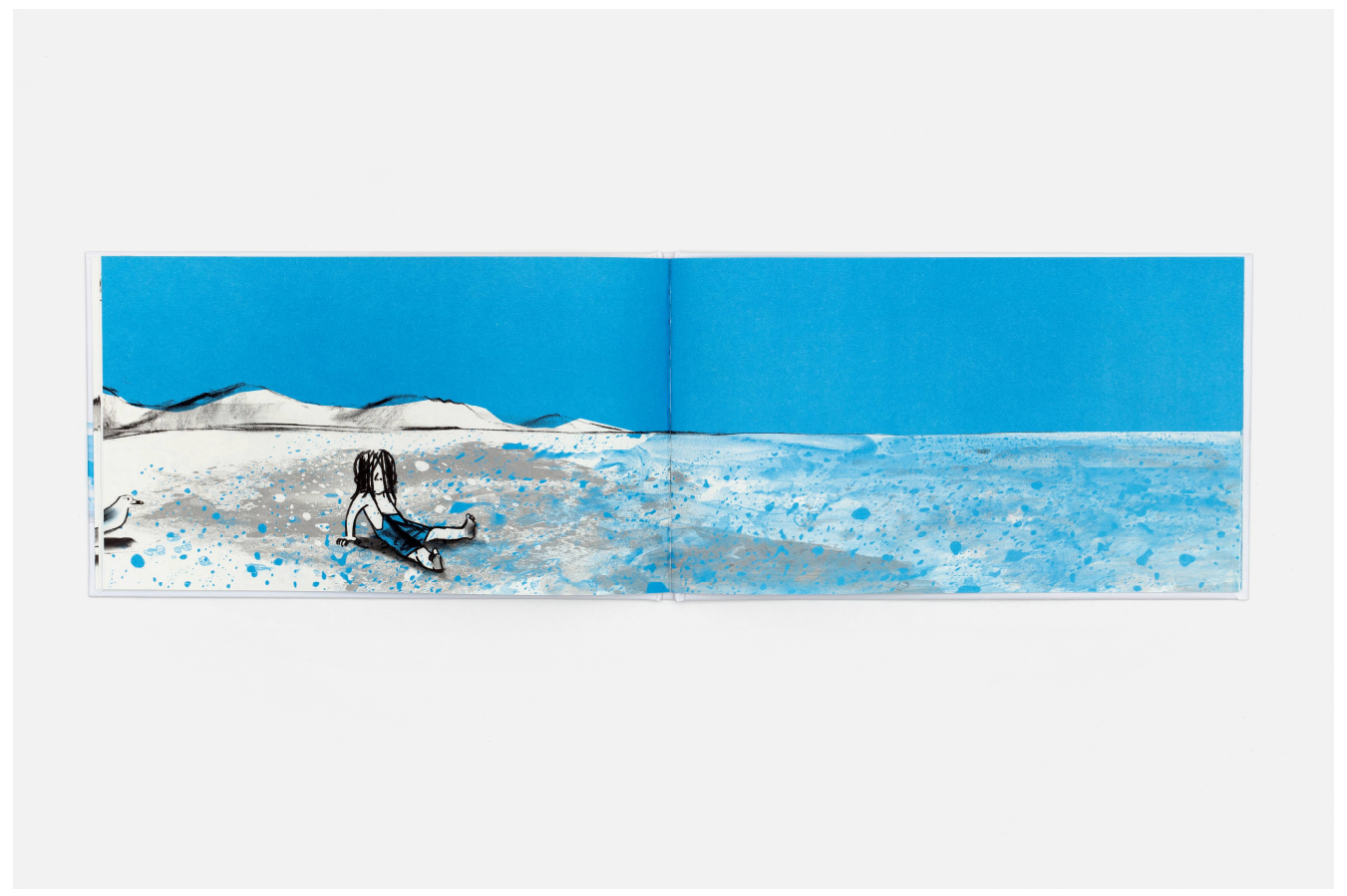

Figure 9. Lee S. (2008), L'onda, Corraini, Mantua.

\section{A Journey toward New Experiences}

Dutch author Charlotte Dematons on the other hand tells of a journey, another recurrent theme of silent books, through the city of Haarlem, its canals and colours [31]. The destination is the Museum of Den Haag and the book invites readers to discover a landscape, which is both natural and cultural, soaked in pictorial references to Flemish art. Past and present, cultural images and natural images blend together as the reader crosses these places together with a walker, a cyclist and some skaters. The windmills, the cows and the clouds are masterpieces of artistic art, which the reader then finds and recognises in the rooms of the museum.

Today, enjoying a most fertile season, a new critical attention and an increased international circulation, the contemporary silent book offers many pedagogical and educational possibilities; it is 
however for us first and foremost a space for stating some rights: the right to cross visual landscapes in the time needed to learn their alphabets, with the silence needed to perceive and experiment the various possibilities offered by the word which reads, describes, informs of reality; the right of the reader to have his own voice, to recognise his own imagination and compare it to that of others; to receive training in order to be able to read the figures and images, demanding of them, and their creators, the cultural responsibility they must assume as visual designers [32].

Silent books are able to provoke inclusive experiences of comparison and negotiation of meaning, particularly linked to the perception of estrangement and disorientation as well as familiarity and the activation of autobiographical, anthropological and cultural memories.

In the vibrant space of contemporary international children's books, today wordless books safeguard and generate new visions able to offer new ways for a poetic and aesthetic education to seeing, but also the possibility to verify the critical ability to read images and improve the learning of visual alphabets; in the context of education which is as attentive to the imagination as to the reality of sensitive things, listening, to meaning, perspectives, forms and contamination of different languages as much as to the relationships between cultural objects, images and readers, they are extraordinarily powerful silent educators.

The silent book states its intentions in contemporary metatextual works such as the books by US author David Wiesner and in the poetic visual masterpiece on migration, Shaun Tan's The Arrival; today the silent book speaks to readers, educators and designers with the clear, eloquent voice of the art form of picture book [33], asking them to pay special attention to the language of images and to silence as an existential and perceptive possibility: dimensions which can still trigger children's wonder, that essential critical resource for a humanity wanting to cultivate the ability to dream, imagine and design its own future.

Conflicts of Interest: The authors declare no conflict of interest.

\section{References}

1. Berger, J. Ways of Seeing; Penguin: London, UK, 2008.

2. Tan, S. The Arrival; Arthur A. Levine: New York, NY, USA, 2007.

3. Tan, S. Foreword. In Visual Journeys through Wordless Narratives: An International Inquiry with Immigrant Children and the Arrival; Arizpe, E., Colomer, T., Martínez-Roldán, C., Eds.; Bloomsbury Academic: London, UK; New York, NY, USA, 2014.

4. Eco, U. Opera Aperta; Bompiani: Milan, Italy, 1962.

5. Arizpe, E.; Colomer, T.; Martínez-Roldán, C. (Eds.) Visual Journeys through Wordless Narratives: An International Inquiry with Immigrant Children and the Arrival; Bloomsbury Academic: London, UK; New York, NY, USA, 2014.

6. Grilli, G.; Terrusi, M. Migrant Readers and Wordless Books: Visual Narratives' Inclusive Experience. Encyclopaideia 2014, 18, 38.

7. Grilli, G.; Terrusi, M. A (Visual) Journey to Italy. In Visual Journeys through Wordless Narratives: An International Inquiry with Immigrant Children and the Arrival; Arizpe, E., Colomer, T., Martínez-Roldán, C., Eds.; Bloomsbury Academic: London, UK, 2014; pp. 217-237.

8. Terrusi, M. Meraviglie mute. Silent Book e Letteratura per L'infanzia; Carocci: Rome, Italy, 2017.

9. Faeti, A. Guardare le figure. In Gli Illustratori Italiani dei libri per L'infanzia; Einaudi: Turin, Italy, 1972; (Reprinted by Donzelli, Rome, Italy, 2011).

10. Beckett, S. Wordless Picturebooks, in Id. In Crossover Picturebooks: A Genre for All Ages; Routledge: London, UK; New York, NY, USA, 2012.

11. Munari, B. Libro Illegibile "MnI"; Corraini: Mantua, Italy, 2009.

12. Mari, I.; Mari, E. La mela e la Farfalla; Babalibri: Milan, Italy, 2004.

13. Farnè, R. Diletto e giovamento. Le immagini e l'educazione; UTET Università: Turin, Italy, 2006.

14. Wiesner, D. Flotsam; Clarion Books: New York, NY, USA, 2006.

15. Petrosino, S. Lo Stupore; Interlinea: Novara, Italy, 2012.

16. Steinlen, T.A. The Sad Tale of Bazouge; Museum of Fine Arts: Boston, MA, USA, 1961.

17. Serafini, L. Codex Seraphinianus; Franco Maria Ricci Editore: Milano, Italy, 1981. 
18. Muybridge, E. The Human and Animal Locomotion Photographs; Taschen Books: Berlin, Germany, 2014.

19. Lee, S. L'onda; Corraini: Mantua, Italy, 2008.

20. Wiesner, D. Free fall; Harper Collins: New York, NY, USA, 1988.

21. Becker, A. Journey; Candlewick Press: Somerville, MA, USA, 2013.

22. Hutchins, P. Changes, Changes; Simon \& Schuster: New York, NY, USA, 1971.

23. Montagu, A. Saremo bambini. In Crescere Sviluppando le Caratteristiche Dell'Infanzia è una Prerogativa Degli Esseri Umani; Red Edizioni: Como, Italy, 1992.

24. Gardini, N. Lacuna. Saggio sul non detto; Einaudi: Turin, Italy, 2014.

25. Lorenzoni, F. I bambini pensano grande. In Cronaca di Un'avventura Pedagogica; Sellerio: Palermo, Italy, 2014.

26. Haskell, G.D. La foresta nascosta. In un anno Trascorso a Osservare la Natura; Einaudi: Turin, Italy, 2014.

27. Bateson, G. Verso Un'ecologia della Mente; Adelphi: Milan, Italy, 1995.

28. Lee, S. La trilogia del Limite; Corraini: Mantua, Italy, 2012.

29. Lee, S. Ombra; Corraini: Mantua, Italy, 2010.

30. Lee, S. Mirror; Corraini: Mantua, Italy, 2003.

31. Dematons, C. Holland op z'n Mooist op reis met de Haagse School; Leopold Gementemuseum: Den Haag, The Netherlands, 2015.

32. Falcinelli, R. Critica Portatile al Visual Design; Da Gutenberg ai Social Network; Einaudi: Turin, Italy, 2014

33. Terrusi, M. Albi illustrati. Leggere, Guardare, Nominare il Mondo nella Letteratura per l'infanzia; Carocci: Rome, Italy, 2012.

(C) 2018 by the authors. Licensee MDPI, Basel, Switzerland. This article is an open access article distributed under the terms and conditions of the Creative Commons Attribution (CC BY) license (http://creativecommons.org/licenses/by/4.0/). 